\title{
Comparative analysis of the hormone production and gene expression profiles in ovine uterus tissue during oestrus cycle synchronized using medroxyprogesterone acetate plus eCG and prostaglandin analogue
}

\section{Análise comparativa da produção de hormônios e perfis de expressão gênica em tecido uterino ovino durante o ciclo estral sincronizado usando acetato de medroxiprogesterona mais eCG e análogo de prostaglandina}

Joaquim de Sousa Lima; ; Márcio da Silva Costa ${ }^{2}$; Júlio Rodrigues Pereira Júnior ${ }^{2}$; Guilherme José Bolzani de Campos Ferreira²; Luciana Rocha Faustino3; Carlos Eduardo Fonseca Alves ${ }^{4}$; Eunice Oba5; Anna Clara Accioly Ferreira6; José Ricardo de Figueiredo7; Cleidson Manoel Gomes da Silva ${ }^{8 *}$

\section{Highlights}

Medroxyprogesterone acetate plus eCG improves the rate of oestrus synchronization. Medroxyprogesterone acetate plus eCG increases the serum concentrations of P4. Gene expression in ovine uterus is not affected by the hormonal protocols.

1 M.e, Postgraduate Program in Zootechnics, Universidade Federal do Piauí, UFPI, Bom Jesus, PI, Brazil. E-mail: joaquimsousa1989@hotmail.com

2 Profs. Drs., Professora Cinobelina Elvas Campus, UFPI, Bom Jesus, PI, Brazil. E-mail: marciocosta@ufpi.edu.br; julioanestesiavet@gmail.com; guilherme.ferreira@ufpi.edu.br

${ }^{3}$ Profa Dra, Ministro Reis Velloso Campus, Universidade Federal Delta do Parnaíba UFDPar, Parnaíba, PI, Brazil. E-mail: Irfaustino@gmail.com

4 Dr., Researcher, Department of Animal Reproduction, Faculty of Veterinary Medicine, Universidade Estadual Paulista, UNESP, Botucatu, SP, Brazil. E-mail: carlos.eduardofa@hotmail.com

${ }_{5}^{5}$ Profa Dra, Department of Animal Reproduction, Faculty of Veterinary Medicine, UNESP, Botucatu, SP, Brazil. E-mail: eunice.oba@unesp.br

${ }^{6}$ Dra., Researcher, Laboratory of Manipulation of Oocytes and Preantral Follicles, LAMOFOPA, Faculty of Veterinary Medicine, Universidade Estadual do Ceará, UECE, Fortaleza, CE, Brazil. E-mail: annaclaraaccioly@yahoo.com.br

7 Prof. Dr., Laboratory of Manipulation of Oocytes and Preantral Follicles, LAMOFOPA, Faculty of Veterinary Medicine, UECE, Fortaleza, CE, Brazil. E-mail: figueiredo.lamofopa@gmail.com

8 Prof. Dr., Institute of Studies of the Humid Tropics, Universidade Federal do Sul e Sudeste do Pará, UNIFESSPA, Xinguara, PA, Brazil. E-mail: gomesvet@hotmail.com

* Author for correspondence

Received: Mar. 25, 2021 - Approved: July 21, 2021 


\section{Abstract}

The combination of medroxyprogesterone acetate (MPA) and gonadotropin chorionic (eCG) has been widely used to synchronize oestrus cycle in sheep, but their effects on the gene expression in uterine tissue are yet to be elucidated. To evaluate the effect of MPA + eCG or prostaglandin analogue (PA) treatments on the rate of oestrus cycle synchronization, as well as further hormone production and gene expression profiles in uterine tissue, 14 Santa Inês ewes were randomly selected. The MPA + eCG group $(n=7)$ received intravaginal insertion of MPA-impregnated sponges for 14 days and was administered 350 IU eCG on the day of sponge withdrawal. The PA group $(n=7)$ was administered two doses of $100 \mu g$ of PA separated by 12 days. The ewes were assessed for the rate of oestrus cycle synchronization and the serum concentrations of progesterone (P4) and estradiol (E2). Additionally, the expression of estrogen receptor $(E R \alpha)$, progesterone receptor (P4R), and immunolocalization of interferon receptor (IFNAR1) in the uterine tissue samples collected $15^{\text {th }}$ day post-mating were examined. The rate of oestrus cycle synchronization was $100 \%(n=7 / 7)$ and $57.14 \%(n=4 / 7)$ in the MPA + eCG and PA groups, respectively. Moreover, the MPA + eCG group exhibited higher serum concentration of P4 than the PA group ( $p<0.05)$. However, the E2 serum concentration did not differ between the two groups ( $p>0.05$ ). The relative expression of $P 4 R$ and $E R \alpha$ mRNA analyzed using real-time PCR and immunodetection of IFNAR1 were similar between the two groups tested $(p>0.05)$. Conclusively, MPA + eCG treatment improved the rate of oestrus cycle synchronization and endogenous P4 production; however, it did not affect the expression of sex steroid receptors and IFNAR1 in uterine ovine tissue.

Key words: Oestrus cycle. Progesterone receptor. Estrogen receptor- $\alpha$. IFNAR1. Sheep.

\section{Resumo}

A combinação de acetato de medroxiprogesterona (MPA) com gonadotrofina coriônica (eCG) é amplamente utilizada para sincronizar o estro de ovelhas, mas seus possíveis efeitos sobre a expressão gênica em tecido uterino não foram elucidados. Para avaliar o efeito dos protocolos MPA + eCG ou análogo de prostaglandina (PA) sobre a taxa de sincronização do estro, bem como na futura produção hormonal e expressão gênica em tecido uterino, 14 ovelhas Santa Inês foram selecionadas. O grupo MPA + eCG $(n=7)$ recebeu a inserção de esponjas impregnadas de MPA por via intravaginal por 14 dias e $350 \mathrm{UI}$ de eCG no dia da retirada da esponja. O grupo PA recebeu duas doses de $100 \mu \mathrm{g}$ de PA administradas com 12 dias de intervalo. As ovelhas foram avaliadas quanto à taxa de sincronização do estro, concentração sérica de progesterona (P4) e estradiol (E2). Além disso, foram examinadas a expressão do receptor de estradiol (ER $\alpha$ ), receptor de progesterona (P4R) e localização do receptor de interferon (IFNAR1), a partir de amostras de tecido uterino coletadas 15 dias após o acasalamento. A taxa de sincronização do estro foi $100 \%(n=7 / 7)$ e $57,14 \%(n=4 / 7)$ nos grupos MPA + eCG e PA, respectivamente. Além disso, o grupo MPA + eCG apresentou maior concentração sérica de P4 em comparação com o grupo PA $(P<0,05)$. No entanto, a concentração sérica de E2 não diferiu entre os grupos testados $(P>0,05)$. A expressão relativa de RNAm para $P 4 R$ e $E R \alpha$ analisado por PCR em tempo real e imunodetecção de IFNAR1 foi semelhante entre os grupos testados $(P>0,05)$. Em conclusão, o tratamento com MPA + eCG melhora a taxa de sincronização do estro e a produção de progesterona endógena; contudo, não afeta a regulação da expressão de receptores de esteroides sexuais e IFNAR1 no tecido uterino de ovinos.

Palavras-chave: Ciclo estral. Receptor de progesterona. Receptor- $\alpha$ de estradiol. IFNAR1. Ovino. 


\section{Introduction}

Artificial insemination can be performed in ewes using natural oestrus cycle. However, the use of spontaneous oestrus cycle is impractical in the assisted reproduction techniques in sheep herds (Letelier et al. 2011). Therefore, great efforts have been put together to test different hormonal treatments for oestrus synchronization with varying dosage of hormones and duration of treatment (Abecia, Forcada, \& GonzálezBulnes, 2012). Currently, most of the oestrus cycle synchronization protocols are mainly based on the administration of prostaglandin analogues or progestagens, thereby aiming to increase reproductive efficiency (Rosasco, Beard, Hallford, \& Summers, 2019). The administration of prostaglandin analogues is an alternative method for controlling reproduction through eliminating the corpus luteum and inducing a subsequent follicular phase with ovulation (Abecia et al., 2012). These protocols also receives notable attention during the breeding season, as they provide good results, are cost-effective, and highly practical (Rosasco eta al, 2019). However, this treatment requires a functional corpus luteum, and thus, they are ineffective during the non-breeding seasons (GonzalezBulnes, Menchaca, Martin, \& Martinez-Ros, 2020).

Conversely, almost all protocols used for the induction and synchronization of oestrus cycle and ovulation involve the insertion of intravaginal devices containing either progesterone controlled drug release (CIDR) inserts or progestagens (sponges impregnated with fluorogestone acetate (FGA) or medroxyprogesterone acetate (MPA)) in sheep (Abecia et al., 2012). Additionally, equine chorionic gonadotropin (eCG) has been widely used in hormonal treatments to induce final follicular growth and ovulation (Cosentino et al., 2019). The administration of eCG at the time of progesterone device withdrawal has been shown to improve the rate of fertility (Martinez-Ros, Rios-Abellan, \& Gonzalez-Bulnes, 2019; Nakafeero, Hassen, \& Lehloenya, 2020) and conception in ewes (Garoussi, Mavadati, Bahonar, \& Ragh, 2020).

Although FGA, CIDR, and MPA devices are efficient in synchronizing oestrus cycle in ewes, differences in the rates of pregnancy, fertility, twinning and fecundity have been recorded (Swelum, Alowaimer, \& Abouheif, 2015). Additionally, a recent study demonstrated the effect of progestagens on the expression profile of genes related to oocyte quality in sheep (Bragança et al., 2021). The authors suggested that this effect probably occurred due to the variations in the chemical structure of these progestogens, thereby resulting in different activities and inducing distinct transcriptome profiles. The results of this study lead to the question of whether the protocols commonly used for oestrus cycle synchronization in sheep can induce significant changes in the uterine environment, especially during the period of maternal recognition in pregnancy. In sheep, this occurs between the 12th and 15th day after mating when the embryo starts synthesizing interferon tau (INFT) (Bazer, Spencer, \& Ott, 1997), a cytokine that acts on the uterine endometrium through interferon receptor subunits, IFNAR1 and IFNAR2 (Brooks \& Spencer, 2015), thereby signaling the presence of the embryo to the maternal body (Bazer, 2013). Additionally, previous research indicated that ER $\alpha$ and P4R can be used as the potential markers for uterine receptivity 
in ruminants (Takahashi, Haneda, Kayano, \& Matsui, 2016; Gao et al., 2019). Therefore, in this study, we aimed to investigate the impact of MPA + eCG and prostaglandin analogue treatments on the rate of oestrus cycle synchronization, as well as further hormonal production and gene expression profiles in the uterine tissue of Santa Inês ewes.

\section{Material and Methods}

\section{Animals}

All procedures performed in this study were conducted in accordance with the guidelines of the Animal Experimentation Ethics Committee of the Federal University of Piauí (protocol number 290/17). All experiments were conducted in accordance with the guidelines for the ethical use of animals in research.

This study was conducted from March to April 2018 at the Professora Cinobelina Elvas Campus, located in Bom Jesus, PI, Brazil (09 $\left.{ }^{\circ} \mathrm{S}, 44^{\circ} \mathrm{W}\right)$. Fourteen multiparous Santa Inês ewes aged 2-4 years, with a mean body weight of $45.9 \pm 7.4 \mathrm{~kg}$, and body condition score of $2.5 \pm 0.4(0=$ extremely thin, $5=$ obese) were selected from a herd of 40 female ewes. All animals were maintained under similar feeding and management conditions. The ewes were maintained in the paddock system and kept in a grazed pasture of Panicum maximum during the day for $8 \mathrm{~h}$. During the night, the ewes were housed in pens, where phosphate mineral licks and water were provided ad libitum. The cyclic ovaries were monitored through ultrasonographic examinations that permitted the exclusion of all pregnant and sick animals.
Experimental design and oestrus cycle synchronization

Fourteen ewes were randomly selected and distributed into two groups (MPA + eCG, $n=7$ and PA, n=7). The MPA + eCG group received intravaginal insertion of MPA-impregnated sponges for 14 days (PROGESPON, Syntex S.A., Buenos Aires, Argentina) and was administered 350 IU eCG i.m. (NOVORMON 5000 IU, Zoetis, São Paulo, Brazil) on the day of sponge withdrawal. The PA group was administered two doses of 100 $\mu \mathrm{g}$ of prostaglandin analogue i.m. (LUTALYSE, Zoetis, São Paulo, Brazil) separated by 12 days.

\section{Oestrus cycle detection and fertilization}

Oestrus cycle was monitored during the same period in both the experimental groups. For this, three adult Santa Ines rams were exposed to the females for at least 30 min every $4 \mathrm{~h}$, from 12 to $42 \mathrm{~h}$ after the second prostaglandin injection or sponge withdrawal. Each ewe was considered to be in oestrus cycle when the ram tried to mate with it, and it remained immobile. After confirmation, the females were subjected to natural mating at the onset and $24 \mathrm{~h}$ later using two Santa Inês rams with proven fertility based on andrologic examinations, and the effect of the ram on fertility was thus avoided. Rate of oestrus cycle synchronization (\%) was calculated as follows: number of ewes in estrus divided by number of ewes on which oestrous synchrony was imposed $\times 100$. 


\section{P4 and E2 assay}

The serum concentrations of P4 and E2 at $15^{\text {th }}$ day after mating were measured using the enzyme-linked immunosorbent assay (ELISA).Blood serumsamples obtained through jugular venipuncture were analyzed using a commercial kit (Progesterone ELISA Kit, No. 402310, Neogen Corporation, Kentucky, USA) according to the manufacturer's instructions. The sensitivity for progesterone and estradiol were 0.35 and $0.03 \mathrm{ng} / \mathrm{mL}$, respectively. The inter- and intra-assay variation coefficients were $\leq 10 \%$ for both the tested hormones tested.

\section{Uterine sample collection}

Uterine biopsies were collected surgically on the $15^{\text {th }}$ day after mating. All females were deprived of food and water for $24 \mathrm{~h}$ before the surgical procedure. In preanesthetic medication, flunixin meglumine $(1.1 \mathrm{mg} / \mathrm{kg})$ was administered. Induction and maintenance were performed using isoflurane (100\%) in addition to local anesthetic block of lidocaine in the surgical field $(9 \mathrm{mg} / \mathrm{kg}$, i.m.) and electrolyte balance replacement with Ringer's lactate solution (10 ml/kg/hour). The surgical technique involved celiotomy with a retroumbilical incision. The reproductive tract was exposed after the opening of the abdominal cavity. A fragment of approximately
$1 \mathrm{~cm}^{2}$ was extracted from each ewe from the caudal third of the uterine horn ipsilateral to the ovary with a corpus luteum. Each sample was sectioned into two parts: one was immediately fixed in 4\% paraformaldehyde for immunohistochemical analysis, and the other was stored in liquid nitrogen until further experiments.

\section{Expression of P $4 R$ and ER $\alpha$ in uterine tissue}

To evaluate the expression levels of progesterone receptor $(P 4 R)$ and estrogen receptor $(E R \alpha)$ genes, total RNA of uterine fragments was extracted using the Trizol $^{\circledR}$ reagent method (Invitrogen, Carlsbad, CA, USA) according to the manufacturer's recommendations and further purified with a PureLink ${ }^{\mathrm{TM}}$ RNA Mini Kit (Anbion ${ }^{\circledR}$, Carlsbad, CA, USA). After extraction, the RNA concentration was determined using the NanoDrop System (Thermo Scientific NanoDrop Products), which was performed using $2 \mu \mathrm{L}$ of material. Before cDNA synthesis, all samples were standardized with the same amount of RNA to minimize qPCR variability. cDNA synthesis was performed using the SuperScript III RT-PCR kit (Invitrogen, Carlsbad, CA, USA) according to the manufacturer's instruction using random primers (Invitrogen, Carlsbad, CA, USA) from 1 ng of total RNA. Primers were designed using Primer 3 software to amplify $P 4 R$ and $E R \alpha$ genes (Table 1). All primer sets were designed to anneal at $60^{\circ} \mathrm{C}$. 
Table 1

Oligonucleotide primers used for PCR analysis of ovine uterine tissue

\begin{tabular}{|c|c|c|c|c|}
\hline Target gene & Primer sequence $\left(5^{\prime} \rightarrow 3^{\prime}\right)$ & Sense & Position & Genbank Accession $\mathrm{N}^{\circ}$. \\
\hline GAPDH & $\begin{array}{l}\text { TGTTTGTGATGGGCGTGAACCA } \\
\text { ATGGCGTGGACAGTGGTCATAA }\end{array}$ & $\begin{array}{c}\text { S } \\
\text { AS }\end{array}$ & 287-309 & $\begin{array}{c}\text { Gl: AJ431207.1 (2016) } \\
\text { Capra hircus GAPDH }\end{array}$ \\
\hline P4R & $\begin{array}{l}\text { TGTCGCCTTAGAAAGTGCTG } \\
\text { GCTGGAGGTATCAGGTTTGC }\end{array}$ & $\begin{array}{c}S \\
A S\end{array}$ & 037-056 & $\begin{array}{c}\text { Gl: U30300.1 (1997) } \\
\text { Ovis aries PR }\end{array}$ \\
\hline$E R \alpha$ & $\begin{array}{l}\text { CAAAGAAGGTGCCAGGATT } \\
\text { TACGGAACCGAGACGATGT }\end{array}$ & $\begin{array}{l}S \\
\text { AS }\end{array}$ & $592-610$ & $\begin{array}{c}\text { GI: AY033393.1 (2016) } \\
\text { Ovis aries ER } \alpha\end{array}$ \\
\hline
\end{tabular}

The reactions were performed in quadruplets using a without cDNA control to avoid possible contamination. The evaluations were performed using the IQ5 Real-Time PCR Detection System (Bio-Rad, Hercules, CA, USA) through relative quantification. PCR products were detected through monitoring the increase in fluorescence emitted by the Power SYBR ${ }^{\circledR}$ Green PCR Master Mix (Applied Biosystems, Carlsbad, CA, USA). For all amplifications, a dissociation curve (melting curve) was used to verify the unspecific amplifications arising due to contamination. The qPCR thermal cycle was as follows: initial denaturation and polymerase activation for 15 min at $94^{\circ} \mathrm{C}$, followed by 40 cycles of $15 \mathrm{~s}$ at $94^{\circ} \mathrm{C}, 30 \mathrm{~s}$ at $60^{\circ} \mathrm{C}$, and $45 \mathrm{~s}$ at $72^{\circ} \mathrm{C}$. The final extension was performed at $72^{\circ} \mathrm{C}$ for $10 \mathrm{~min}$. The delta-delta-CT method was applied to transform CT values into normalized relative mRNA levels (Livak \& Schmittgen, 2001).

\section{Immunohistochemistry}

The uterine tissue fragments collected after the surgical procedure were fixed in $4 \%$ paraformaldehyde for 12 h. Subsequently, they were subjected to standard histological processing through inclusion in paraffin (HISTOPAR ${ }^{\circledR}$, Erviegas, São Paulo, Brazil). The tissue blocks were cut using a microtome (Leica RM2125 RT, Leica Biosystems Nussloch $\mathrm{GmbH}$, Heidelberger, Germany) that was adjusted to $4.0 \mu \mathrm{m}$. The obtained sections were placed on silanized slides, deparaffinized in xylol (2 times/10 min each), rehydrated in a series of ethanol solutions with decreasing concentrations using the following sequence: $100 \%, 90 \%$, and $70 \%$ for 5 min each.

The immunohistochemistry reaction was performed using the peroxidase-labeled antibody method and a polyclonal antibody against IFNAR1 (Phospho-IFNAR1-S535/ S539, Abnova Corporation, Taiwan, China) detected by 3 '-diaminobenzidine (DAB). The slides were dewaxed in xylene and rehydrated in graded ethanol solutions: $100 \%, 95 \%$ and $85 \%$. For antigenic recovery, the slides were incubated in citrate buffer ( $\mathrm{pH}$ 6.0) in a pressure cooker (Pascal ${ }^{\circledR}$; Dako, Carpinteria, CA, USA). Subsequently, the slides were placed on an automatic immunohistochemistry platform (Autostainer Dako Cytomation, Carpinteria, CA, USA). The anti-IFNAR1 antibody was diluted at a ratio of 1:200. Immunohistochemical staining was performed using a polymer system (Histofine, code 414154F, Nichirei Biosciences, Tokyo, Japan). Subsequently, the sections were counterstained with Harris hematoxylin. A negative control was obtained 
through removing the primary antibody.

The intensity of immunostaining in the uterine endometrium samples was assessed using the optical microscopy as described by Anjos et al. (2019). Briefly, the immunoreaction score (0-4) was calculated as the percentage of positive cells: score 0 (absence of staining), 1 (1-25\% positive cells), 2 (26-50\% positive cells), 3 (51-75\% positive cells), and 4 (>75\% positive cells).

\section{Statistical analysis}

Data analyses were performed using the Statistical Analysis System for Windows SAS $^{\circledR}$ software (University Edition version). The rate of oestrus cycle synchronization was presented descriptively. Endogenous P4 and E2 concentrations were analyzed using ANOVA and the linear regression model (PROC GLM). The mRNA expression levels of $P 4 R$ and $E R \alpha$ were analyzed using the Student's t-test. Data are presented as mean $\pm \mathrm{SEM}$, and results were considered significant at $p<0.05$.

\section{Results and Discussion}

The effects of hormonal treatments on the rate of oestrus cycle synchronization are presented in Figure 1. The rates of oestrus cycle synchronization were $100 \%(n=7 / 7)$ and $57.14 \%(n=4 / 7)$ in the MPA + eCGandPA groups, respectively. These results indicate that MPA treatment was effective for oestrus cycle synchronization in sheep and its efficiency could be attributed to the efficient delivery of progesterone during the treatment (Abecia et al, 2012). Additionally, the administration of eCG at the time of sponge withdrawal has been a valuable strategy for increasing the conception rates compared to using MPAalone (Garoussi et al., 2020). A similar response has been observed in previous studies (Nakafeero et al., 2020; Garoussi et al, 2020), wherein long-term treatment of P4 in combination with eCG has been implemented. Therefore, the administration of eCG is essential for the induction of ovulation and for precise oestrus cycle synchronization in sheep (Martinez-Ros \& Gonzalez-Bulnes, 2019).

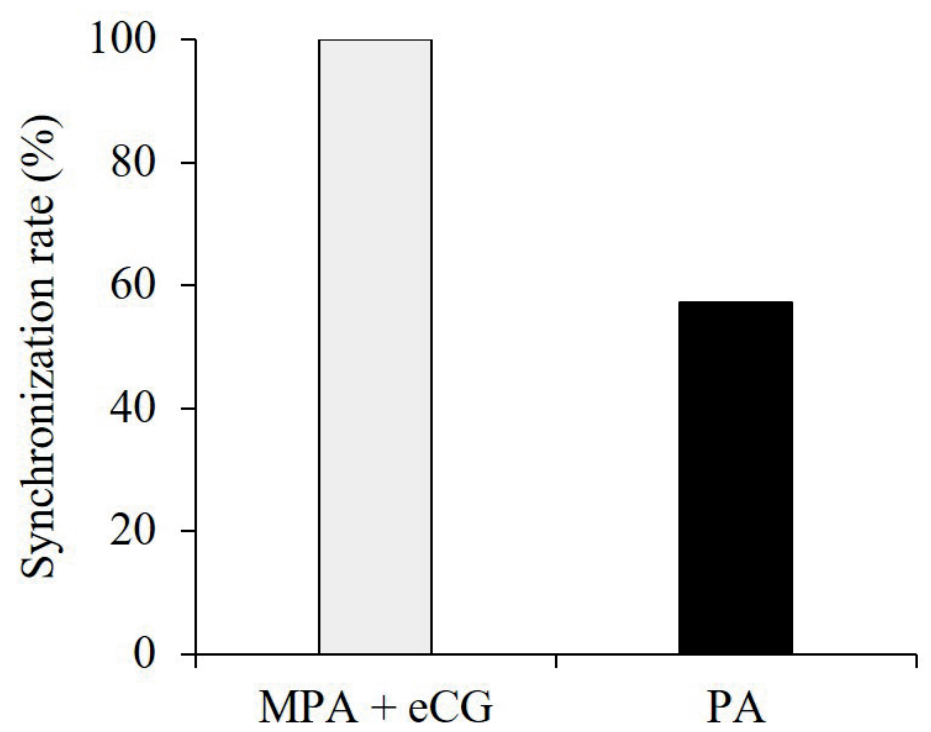

Figure 1. Rate of oestrus cycle synchronization in Santa Inês ewes using MPA + eCG or PA. 
The successful oestrus cycle synchronization protocol must be able to induce ovulation of a healthy follicle, which would result in the formation of functional corpus luteum that will in turn produce high concentration of P4 (Tortorella et al., 2013). Under normal conditions, if no fertilization occurs during an oestrus cycle, the corpus luteum regresses at $\sim 12-15$ days after previous oestrus cycle in ewes (Bartlewski, Baby, \& Giffin, 2011). In the present study, the endogenous circulating concentrations of P4 on the 15th day after mating were significantly higher in the MPA + eCG $(p<0.05)$ group than in the PA group (Figure 2). These results indicate that a treatment based on 14 days of exposure to MPA with the administration of eCG at the time of sponge withdrawal constitutes an interesting alternative to increase the endogenous progesterone concentrations after ovulation in ewes. Possible explanations for this effect could be related to higher quality or accessory CL formation. This hypothesis is supported by the findings of Tortorella et al. (2013), who reported increased luteal volume, serum $\mathrm{P} 4$ concentrations, and pregnancy rates after eCG treatment in cattle. According to Rostami, Hajizadeh, Shahir and Aliyari (2017), high level of progesterone is desirable, since the presence of large amount of this hormone has been related to improved embryonic survival and reduced early pregnancy losses in ruminants.

In the present study, we observed low E2 production ( $1 \mathrm{ng} / \mathrm{ml}$ ) on 15th day after mating in both groups ( $p>0.05$, Figure 2). Similar results were observed by Arsoy and Sağmanlıgil (2018), who worked with white Karaman ewes, and reported a decrease in the serum concentrations of E2 to its minimum level at 15th day of the cycle $(0.35 \pm 0.15 \mathrm{ng} /$
$\mathrm{mL}$ ). Additionally, another study verified that during the luteal phase, E2 concentrations were variable and there was a sharp decrease $(p<0.05)$ from day 16 to 17 (Bartlewski et al., 1999). These results are interesting because the interactions between estradiol and uterine receptivity are not clearly understood in ewes. Moreover, our results are consistent with those previously reported in mice ( $\mathrm{Ma}$, Song, Das, Paria, \& Dey, 2003), where the authors verified that the duration of the window of uterine receptivity is drastically curtailed in the presence of higher levels of estradiol. In heifers, a correlation between E2 production by ovarian follicles and the timing of luteolysis has been demonstrated (Araujo et al., 2009). However, the role of endogenous E2 from follicles as a stimulator of luteolysis in ewes requires further investigation.

Progesterone and estrogen are important hormones in the regulation of reproductive processes in mammals (Okumu et al., 2010). Therefore, the knowledge of $E R \alpha$ and $P 4 R$ gene expression is critical to understand the mechanisms that control successful embryo implantation and maintenance of pregnancy in ruminants. It is well established that the effects of P4 and E2 on the endometrium are mediated primarily through the binding to their nuclear receptors, $P 4 R$ and $E R \alpha$, respectively, which are located within the target cells in the uterus (Takahashi et al, 2016; Robertshaw, Blan, \& Das, 2016). In this study, real-time PCR showed that ER $\alpha$ and P4R mRNA levels were similar between the two groups tested (Figure 3 ). These results suggest that the molecular programming of the uterus with respect to the specific expression of P4R and ER $\alpha$ was not altered by hormonal protocols used for estrus synchronization. These results are similar to 

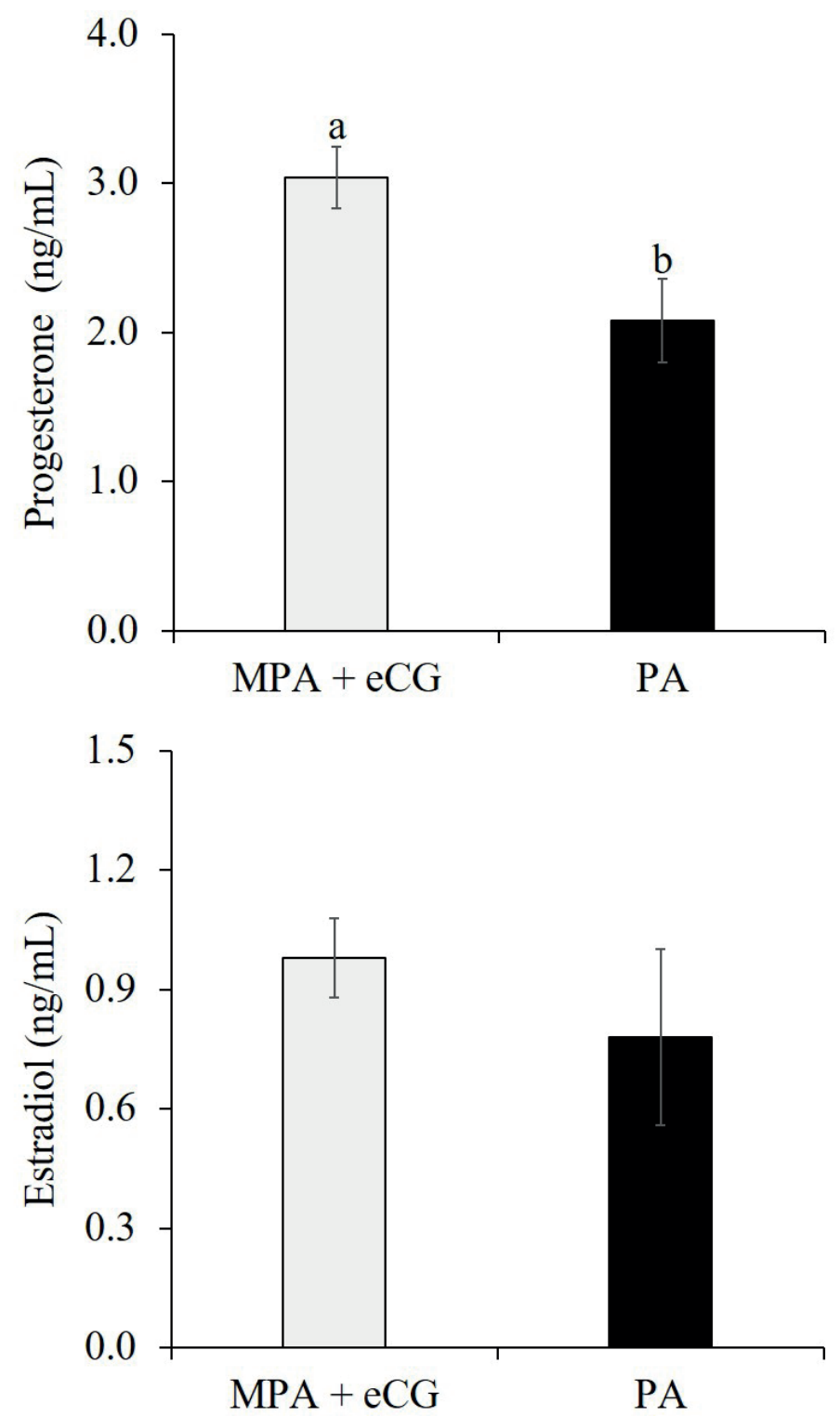

Figure 2. Serum progesterone and estradiol levels at $15^{\text {th }}$ day after fertilization in Santa Inês ewes synchronized with MPA + eCG or PA. Mean values with distinct superscripts are considered statistically different $(p<0.05)$.

those reported by Ruiz-González et al. (2011, 2012), who tested fluorogestone acetate (FGA) alone and prostaglandin analogs for oestrus cycle synchronization in the Manchega sheep breed. Conversely, another study verified that oestrus cycle synchronization using progestagens showed a decrease in $\mathrm{ER} \alpha$ and $\mathrm{P} 4 \mathrm{R}$ protein immunoexpression in most of the oviductal and uterine cells when compared to prostaglandin analog treatment in sheep (García-Palencia et al., 2007). These contradictory results may be mainly due to differences between the hormonal treatments used for oestrus cycle synchronization, moment of evaluation of sex steroid receptor expression, and ovine breed. 

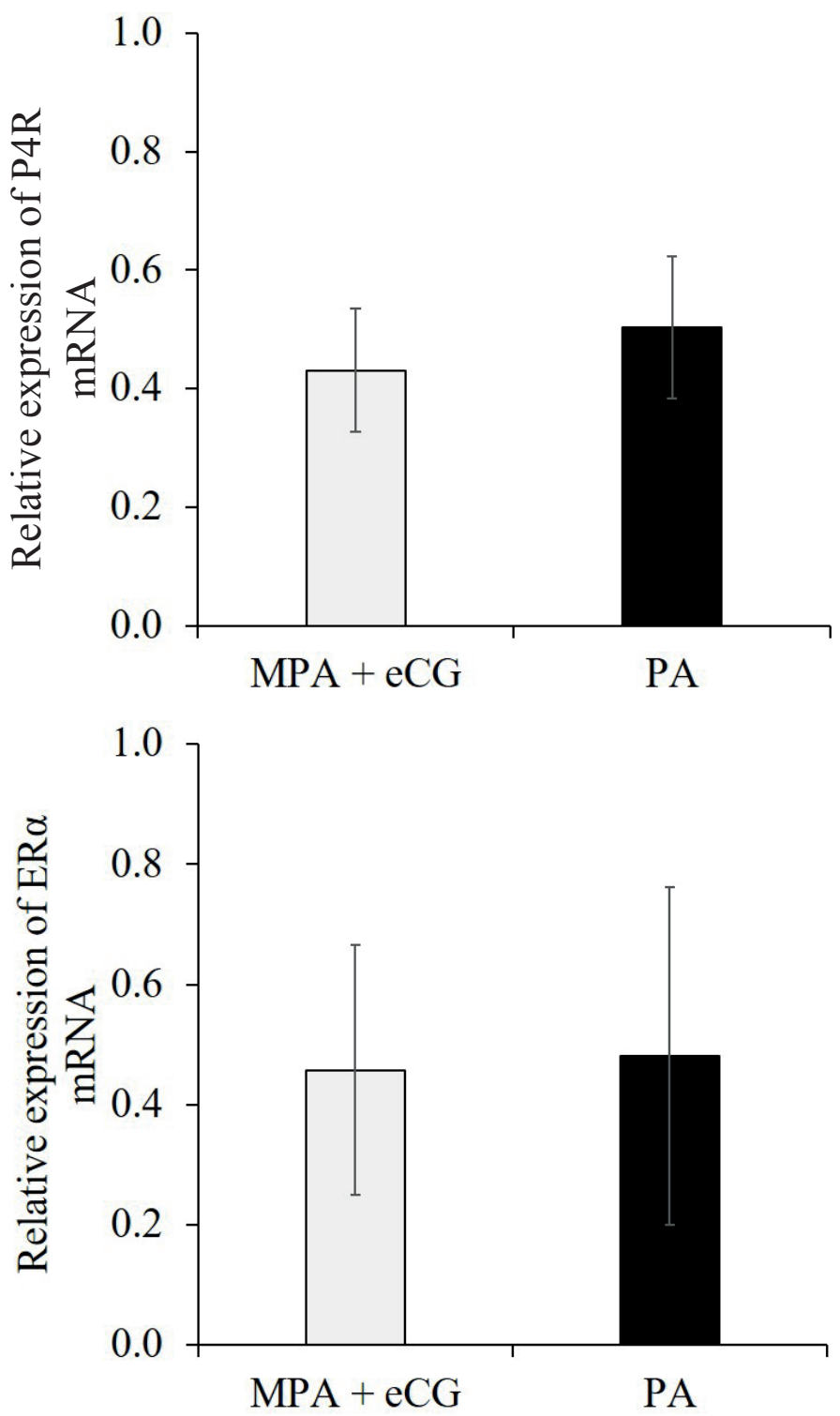

Figure 3. Relative expression of $P 4 R$ and $E R \alpha m R N A$ at $15^{\text {th }}$ day after fertilization in Santa Inês ewes synchronized with MPA + eCG or PA.

Regarding the detection of IFNAR1 in uterine tissue using immunohistochemistry, strong staining with a score varying from $3(51-75 \%$ of positive cells) to 4 ( $>75 \%$ of positive cells) was found in both groups (Figure 4). These results demonstrate that both treatments seem to promote uterine receptivity for embryo implantation in the presence of IFNAR1 immunoexpression. After this qualitative analysis, we hypothesized that IFNAR1 expression is not directly influenced by endogenous steroid hormone concentrations, but is indeed regulated by possible conceptus presence. In sheep, between the $12^{\text {th }}$ and $15^{\text {th }}$ day after mating, the embryo synthesizes interferon tau (INFT), a cytokine that acts on the uterine endometrium through interferon receptor subunits, IFNAR1 
and IFNAR2 (Rosenfeld, Han, Alexenko, Spencer, \& Roberts, 2002), thereby signaling the presence of the embryo to the maternal body (Brooks \& Spencer, 2015). Indeed, some studies have suggested that IFNT abrogates the development of the luteolytic mechanism through silencing the expression of OTR to prevent pulsatile release of luteolytic PGF2 $\alpha$ by the uterine epithelium (Bazer, 2013). Nonetheless, there is a gap in the literature regarding the impact of exogenous hormonal treatments at the molecular level on the environment of the uterus in small ruminants.

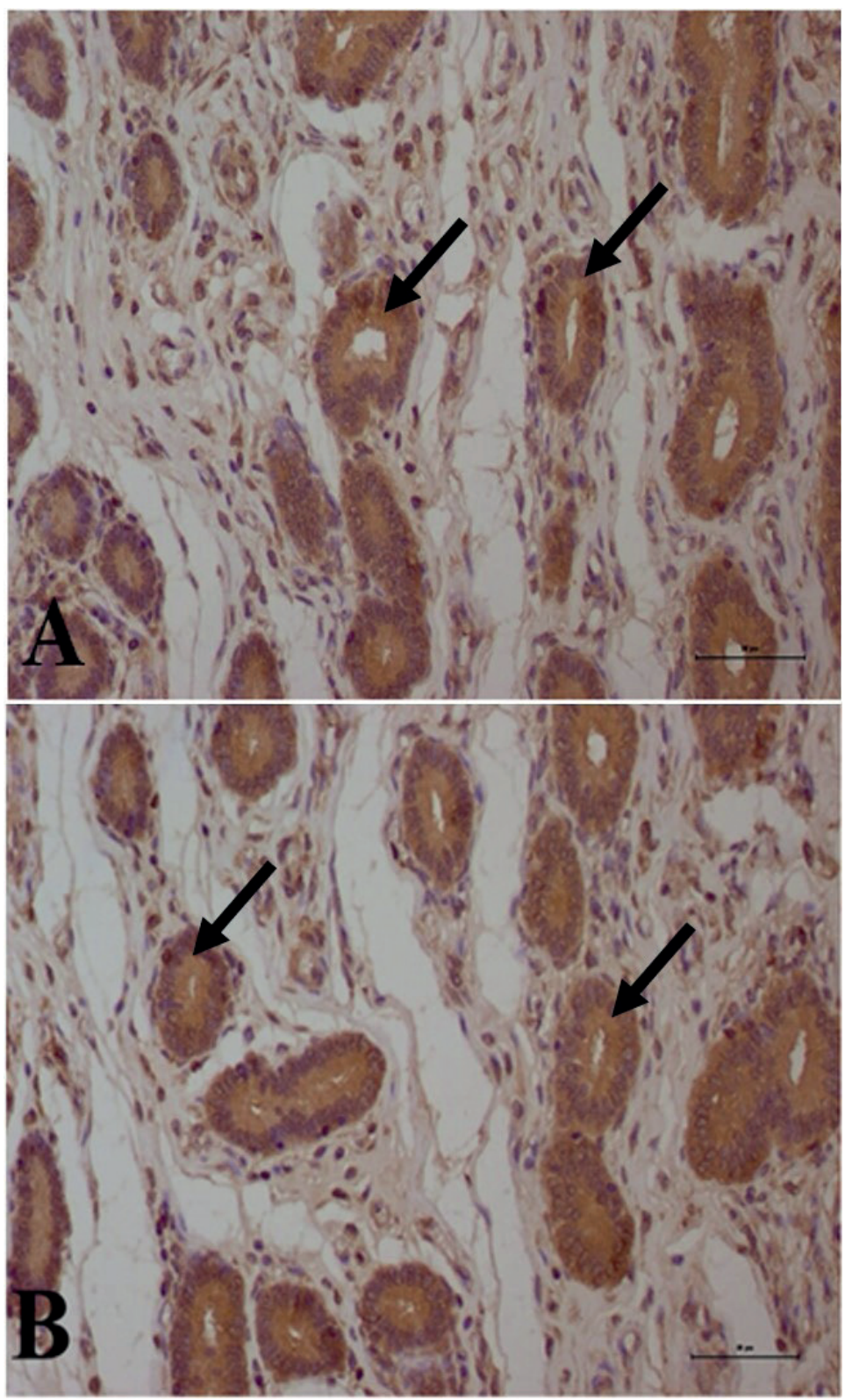

Figure 4. Immunohistochemical localization of IFNAR1 at $15^{\text {th }}$ day after fertilization in ovine uterus synchronized with MPA + eCG or PA. Ovine uterus synchronized with A) MPA + eCG and B) PA. Black arrows indicate the presence of endometrial glands. 


\section{Conclusion}

The results obtained in this study suggest that MPA + eCG treatment improved the rate of oestrus cycle synchronization along with endogenous P4 production; however, it did not affect the expression of $E R \alpha, P 4 R$, and IFNAR1 in uterine ovine tissue. Therefore, the use of hormonal treatments that promote the induction of endogenous P4 seems to be an interesting strategy for enhancing the reproductive efficiency of Santa Inês ewes.

\section{Acknowledgement}

This study was financially supported through a fund received from Edital 01/2016 - Universal ref. n. 425339-2016-5. We thank Colégio Técnico de Bom Jesus CTBJ for kindly providing the experimental animals used in this study. Lima J.S. received a scholarship from CNPq/Brazil.

\section{Declaration of Competing Interest}

The authors declare that they have no competing interests.

\section{References}

Abecia, J. A., Forcada, F., \& González-Bulnes, A. (2012). Hormonal control of reproduction in small ruminants. Animal Reproduction Science, 130(3-4), 173-179. doi:10.1016/j. anireprosci.2012.01.011

Anjos, D. S. dos, Vital, A. F., Lainetti, P. F., Leis, A.

F., F., Dalmolin, F., Elias, F., Fonseca-Alves, C. E. (2019). Deregulation of VEGFR-2 and PDGFR expression and microvascular density in a triple-negative model of canine malignant mammary tumors with lymph node or lung metastasis. Veterinary Science, 6(1), 1-12. doi: 10.3390/vetsci 6010003

Araujo, R. R., Ginther, O. J., Ferreira, J. C., Palhão, M. M., Beg, M. A., \& Wiltbank, M. C. (2009). Role of follicular estradiol-17beta in timing of luteolysis in heifers. Biology of Reproduction, 81(2), 426-437. doi: 10.1095/biolreprod.108.073825

Arsoy, D., \& Sağmanlıgil, V. (2018). Reproductive cycles in white Karaman ewes: comparison of ovarian hormone secretion and reproductive behavior in non-pregnant and pregnant ewes in semiintensive conditions. Acta Scientiarum. Animal Sciences, 40(1), 1-7. doi: 10.4025/ actascianimsci.v40i1.39908

Bartlewski, P. M., Baby, T. E., \& Giffin, J. L. (2011). Reproductive cycles in sheep. Animal Reproduction Science, 124(3-4), 259-268. doi: 10.1016/j.anireprosci.2011.02.024

Bartlewski, P. M., Beard, A. P., Cook, S. J., Chandolia, R. K, Honaramooz, A., \& Rawlings, N. C. (1999). Ovarian antral follicular dynamics and their relationships with endocrine variables throughout the oestrous cycle in breeds of sheep differing in prolificacy. Journal of Reproduction and Fertility, 115(1), 111-124. doi: 10.1530/ jrf.0.1150111

Bazer, F. W. (2013). Pregnancy recognition signaling mechanisms in ruminants and pigs. Journal of Animal Science and Biotechnology, 4(1), 1-10. doi: 10. 1186/2049-1891-4-23

Bazer, F. W., Spencer, T. E., \& Ott, T. L. (1997). Interferon tau: a novel pregnancy 
recognition signal. American Journal of Reproductive Immunology, 37(6), 412-20. doi: 10.1111/j.1600-0897.1997.tb00253.x

Bragança, G. M., Batista, R. I. T. P., SouzaFabjan, J. M. G., Alfradique, V. A. P., Arashiro, E. K. N., Pinto, P. H. N.,... Brandão, F. Z. (2021). Exogenous progestogens differentially alter gene expression of immature cumulus-oocyte complexes in sheep. Domestic Animal Endocrinology, 74, 106518. doi: 10.1016/j. domaniend.2020.106518

Brooks, K., \& Spencer, T. (2015). Biological roles of interferon tau (IFNT) and type I IFN receptors in elongation of the ovine conceptus. Biology of Reproduction, 92(2), 1-10. doi: 1095/biolreprod.114.124156

Cosentino, I. O., Balaro, M. F. A., Arashiro, E. K. N., Santos, J. D. R., Carvalho, A. B. S., Clariget, R. P.,... Brandão, F. Z. (2019). Hormonal protocols for early resynchronization of ovulationinewes:Theuseofprogestagens, eCG, and inclusion of early pregnancy diagnosis with color Doppler ultrasound. Theriogenology, 133(15), 113-118. doi: 10.1016/j.theriogenology.2019.04.033

Gao, X., Zhang Q., Zhu, M., Li, X., Guo, Y., Pang, J.,... Wang, F. (2019). Effects of I-arginine on endometrial estrogen receptor $\alpha / \beta$ and progesterone receptor expression in nutrient-restricted sheep. Theriogenology, 138(15), 137-144. doi: 10.1016/j.theriogenology.2019.07.018

García-Palencia, P., Sánchez, M. A., Nieto, A., Vilar, M. P., González, M., Veiga-Lopez, A.,... Flores, J. M. (2007). Sex steroid receptor expression in the oviduct and uterus of sheep with estrus synchronized with progestagen or prostaglandin analogues. Animal Reproduction Science, 97(1-2), 25-35. doi: 10.1016/j. anireprosci.2006.01.001

Garoussi, M. T., Mavadati, O., Bahonar, M., \& Ragh, M. J. (2020). The effect of medroxyprogesterone acetate with or without eCG on conception rate of fat-tail ewes in out of breeding season. Tropical Animal Health and Production, 52(4), 1617-1622. doi: 10.1007/s11250-019-02 $159-8$

Gonzalez-Bulnes, A., Menchaca, A., Martin, G. B., \& Martinez-Ros, P. (2020). Seventy years of progestagen treatments for management of the sheep oestrous cycle: where we are and where we should go. Reproduction, Fertility and Development, 32(5), 441-452. doi: 10.1071/RD18477

Letelier, C. A., Contreras-Solisa, I., GarcíaFernández, R. A., Sánchez, M. A., GarcíaPalencia, P., Sánchez, B., Gonzalez-Bulnes, A. (2011). Effects of oestrus induction with progestagens or prostaglandin analogues on ovarian and pituitary function in sheep. Animal Reproduction Science, 126(1-2), 61-69. doi: 10.1016/j. anireprosci.2011.04.012

Livak, K. J., \& Schmittgen, T. D. (2001). Analysis of relative gene expression data using real time quantitative PCR and the 2(-Delta Delta C(T)) method. Methods, 25(4), 402408. doi: 10.1006/meth. 2001.1262

Ma, W., Song, H., Das, S. K., Paria, B. C., \& Dey, S. K. (2003). Estrogen is a critical determinant that specifies the duration of the window of uterine receptivity for implantation. Proceedings of the National Academy of Sciences, 100(5), 2963-2968. doi: 10.1073/pnas.0530162100 
Martinez-Ros, P., \& Gonzalez-Bulnes, A. (2019). Efficiency of CIDR-based protocols including $\mathrm{GnRH}$ instead of eCG for estrus synchronization in sheep. Animals, 9(4), 1-11. doi: 10.3390/ani9040146

Martinez-Ros, P., Rios-Abellan, A., \& Gonzalez-Bulnes, A. (2019). Influence of progesterone-treatment length and eCG administration on appearance of estrous behavior, ovulatory success and fertility in sheep. Animals, 9(1), 1-9. doi: 10.3390/ ani9010009

Nakafeero, A., Hassen, A., \& Lehloenya, K. C. (2020). Investigation of ram effect and eCG usage in progesterone based oestrous synchronization protocols on fertility of ewes following fixed time artificial insemination. Small Ruminant Research, 183, 106034. doi: 10.1016/j. smallrumres.2019.106034

Okumu, L. A., Forde, N., Fahey, A. G., Fitzpatrick, E., Roche, J. F., Crowe, M. A., \& Lonergan, P. (2010). The effect of elevated progesterone and pregnancy status on mRNA expression and localisation of progesterone and oestrogen receptors in the bovine uterus. Reproduction, 140(1), 143-153. doi: 10.15 30/REP-10-0113

Robertshaw, I., Blan, F., \& Das, S. K. (2016). Mechanisms of uterine estrogen signaling during early pregnancy in mice: an update Journal of Molecular Endocrinology, 56(3), 127-138. doi: 10.1530/JME-15-0300

Rosasco, S. L., Beard, J. K., Hallford, D. M., \& Summers, A. F. (2019). Evaluation of estrous synchronization protocols on ewe reproductive efficiency and profitability. Animal Reproduction Science, 210, 106191. doi: 10.1016/j.ani reprosci.2019.106191
Rosenfeld, C.S., Han, C., Alexenko, A.P., Spencer, T. E., \& Roberts, R. M. (2002). Expression of interferon receptor subunits, IFNAR1 and IFNAR2, in the ovine uterus. Biology of Reproduction, 67(3), 847-853. doi: 10.1095/biolreprod.102.004267

Rostami, B., Hajizadeh, R., Shahir, M. H., \& Aliyari, D. (2017). The effect of post-mating hCG or progesterone administration on reproductive performance of Afshari $\times$ Booroola-Merino crossbred ewes. Tropical Animal Health and Production, 49(2), 245-250. doi: 10.1007/s11250016-1183-6

Ruiz-González, I., Sánchez, M. A., GarcíaFernández, R. A., García-Palencia, P., Sánchez, B., Letelier, C. A., Flores, J. M. (2011). Endometrial expression of IFNAR-1 and oxytocin receptor (OTR) is not improved by prostaglandin analogues when compared to progestagens in ewes. Reproduction in Domestic Animals, 47(2), 274-280. doi: 10.1111/j.1439-0531.2011. 01852.x

Ruiz-González, I., Sánchez M. A., GarcíaPalencia P., Sánchez B., GarcíaFernández, R. A., González-Bulnes A., \& Flores, J. M. (2012). Differences in uterine immunoexpression of $\mathrm{PR}, \mathrm{ER} \alpha$ and OTR when comparing prostaglandinto progestagen-based protocols for ovine estrus synchronization. Animal Reproduction Science, 133(1), 93-100. doi: 10.1016/j.anireprosci.2012.06.015

Swelum, A. A., Alowaimer, A. N., \& Abouheif, M. A. (2015). Use of fluorogestone acetate sponges or controlled internal drug release for estrus synchronization in ewes: effects of hormonal profiles and reproductive performance. 
Theriogenology, 84(4), 498-503. doi: 10. 1016/j.theriogenology.2015.03.018

Takahashi, H., Haneda, S., Kayano, M., \& Matsui, M. (2016). Differences in progesterone concentrations and mRNA expressions of progesterone receptors in bovine endometrial tissue between the uterine horns ipsilateral and contralateral to the corpus luteum. Journal of Veterinary Medical Science, 78(4), 613-618. doi: 10. 1292/jvms.15-0366
Tortorella, R. D., Ferreira, R., Santos, J. T., Andrade, O. S., Neto, Barreta, M. H., Oliveira, J. F.,... Neves, J. P. (2013). The effect of equine chorionic gonadotropin on follicular size, luteal volume, circulating progesterone concentrations, and pregnancy rates in anestrous beef cows treated with a novel fixed-time artificial insemination protocol. Theriogenology, 79(8), 1204-1209. doi: 10.1016/j.therioge nology. 2013.02.019 
